\title{
Analisa Kualitas Daya Listrik Instalasi Wing Amerta RSUP Sanglah Denpasar
}

\author{
I Putu Meyyasa ${ }^{1,2}$, Rukmi Sari Hartati ${ }^{2}$, I.B. Gede Manuaba ${ }^{2}$ \\ [Submission: 14-05-2019, Accepted: 15-07-2019]
}

\begin{abstract}
The Wing Amerta installation is part of the Sanglah General Hospital in Denpasar that has outpatient / polyclinic services, inpatient care, delivery rooms, operating rooms, and support services to facilitate the needs of people who want more comfortable services. Electricity consumption comes from 4 equipment groups, namely: air conditioning equipment group which is equal to $\mathbf{7 6 . 3 4 \%}$ followed by other equipment groups of $17.22 \%$, medical equipment group of $3.23 \%$, the lowest consumption is in the lighting group of $3.21 \%$. Payment of electricity consumption in 2016, 2017 and 2018 is 1,390,145,617 rupiah. From the total cost of energy expenditure as a whole, there is an excess consumption cost of reactive power (KVARH) which must be paid at $199,578,425$ rupiah, with an annual average of 66,526,141 rupiahs or an average of 5,543,845 rupiah per month. To improve the quality of electric power, it is necessary to measure the electrical data to be analyzed. The results of the analysis, measurement and calculation showed that the power capacity of 555KVA with cosphi of 0.75 requires the improvement of the power factor to 0.86 or 0.98 with the installation of bank capacitors with a capacity of 162.465 KVAR or 285.575 KVAR. By taking into account the availability of bank capacitors in the market and the addition of power loads in the following year, the required bank capacitor recommendations are $360 \mathrm{KVAR}$. This investment will return to 1.8 years and after the second year and so on, is the profit or efficiency of hospital expenditure of Rp. 5,543,845, - every month or Rp. 66,526,141, every year, and is expected to: Maximize power consumption (KVA), avoid overloading the transformer (overload) and avoid increasing current / temperature on the cable.
\end{abstract}

Keywords: Power Quality, Cosphi, Capacitor Bank, Hospital Efficiency.

Intisari - Instalasi Wing Amerta adalah merupakan bagian dari RSUP Sanglah Denpasar yang memiliki pelayanan rawat jalan / poliklinik, rawat inap, kamar bersalin, kamar operasi, dan layanan penunjang untuk memfasilitasi kebutuhan masyarakat yang menghendaki pelayanan lebih nyaman. Konsumsi energi listrik berasal dari 4 kelompok peralatan yaitu: kelompok peralatan penataan udara (AC) yaitu sebesar 76,34\% diikuti oleh kelompok peralatan lain sebesar $17,22 \%$, kelompok peralatan medis sebesar $3,23 \%$, konsumsi terkecil adalah pada kelompok penerangan sebesar 3,21\%. Pembayaran konsumsi listrik tahun 2016, 2017 dan 2018 sebesar 1.390.145.617 rupiah.

1,2 RSUP Sanglah, Jln. Diponegoro, Denpasar 80114, INDONESIA, (telp: 0361-227911,e-mail:pmeyyasa@yahoo.co.id)

2 Jurusan Teknik Elektro, Fakultas Teknik Universitas Udayana, Jln. Kampus Bukit Jimbaran 80361 INDONESIA, (telp: 0361-703315;e-mail:rukmisari@unud.ac.id, ibgmanuaba@unud.ac.id)

I Putu Meyyasa: Analisa Kualitas Daya Listrik ...
Dari besarnya biaya belanja energi secara keseluruhan, terdapat biaya konsumsi kelebihan daya reaktif (KVARH) yang harus dibayar sebesar 199.578.425 rupiah, dengan rata-rata pertahun 66.526.141 rupiah atau rata-rata perbulan 5.543.845 rupiah. Untuk meningkatkan kualitas daya listrik perlu dilakukan pengukuran data besaran listrik yang akan dianalisa. Hasil analisa, pengukuran serta perhitungan didapat kapasitas daya 555KVA dengan cosphi sebesar 0,75 memerlukan perbaikan faktor daya menjadi 0,86 atau 0,98 dengan pemasangan kapasitor bank dengan kapasitas 162,465 KVAR atau 285,575 KVAR. Dengan memperhitungkan ketersediaan kapasitor bank di pasaran serta penambahan beban daya di tahun berikutnya, maka rekomendasi kapasitor bank yg dibutuhkan sebesar 360 KVAR. Investasi ini akan kembali pada 1,8 tahun dan setelah tahun ke dua dan seterusnya, merupakan keuntungan atau efisiensi pengeluaran Rumah Sakit sebesar Rp. 5.543.845,- setiap bulannya atau Rp. 66.526.141,- setiap tahunnya, serta diharapkan dapat : Memaksimalkan pemakaian daya (KVA), menghindari kelebihan beban trafo (overload) dan menghindari kenaikan arus / suhu pada kabel.

Kata Kunci: Kualitas Daya, Cosphi, Kapasitor Bank, Efisiensi Rumah Sakit.

\section{PENDAHULUAN}

Instalasi Wing Amerta adalah merupakan bagian dari RSUP Sanglah Denpasar yang memiliki pelayanan rawat jalan / poliklinik, rawat inap, kamar bersalin, kamar operasi, dan layanan penunjang untuk memfasilitasi kebutuhan masyarakat yang menghendaki pelayanan lebih nyaman, diresmikan dan dibuka pada tanggal 30 Desember 2004 sebagai perwujudan impian masyarakat untuk memiliki sebuah rumah sakit yang bertaraf internasional di Bali.

Konsumsi energi listrik tahun 2016, 2017 dan 2018 sebesar 1.390.145.617 rupiah. Dari besarnya biaya belanja energi secara keseluruhan, terdapat biaya konsumsi kelebihan daya reaktif (KVARH) sebesar 199.578.425 rupiah, dengan rata-rata pertahun 66.526.141 rupiah dan rata-rata perbulan 5.543.845 rupiah.

Berdasarkan latar belakang di atas, dalam penelitian ini akan dilakukan studi terhadap kualitas daya listrik di Instalasi Wing Amerta RSUP Sanglah Denpasar melalui proses pengukuran untuk mengetahui masalah apa saja yang mempengaruhi serta solusi yang akan diberikan. Dengan dasar ini dapat direkomendasikan kepada pihak manajemen RS Sanglah untuk merencanakan dan melaksanakan program. Keterbaruan kegiatan ini dilakukan karena belum ada yang meneliti tentang analisa kualitas daya listrik di RSUP Sanglah Denpasar.

\section{PERBAIKAN DAYA REAKTIF}

\section{A. Daya Listrik}

p-ISSN:1693 - 2951; e-ISSN: 2503-2372

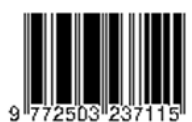


Dalam sistem tenaga listrik, daya merupakan jumlah energi yang digunakan untuk melakukan kerja atau usaha. Ada tiga macam daya listrik yang di kenal dengan segitiga daya [1], [2] [3], [4], [5] dapat dilihat pada Gambar 1.

1) Daya Nyata (P)

Daya nyata ( real power ) disebut juga dengan daya aktif (active power) dengan satuan W (Watt). Daya nyata adalah daya yang diperlukan oleh beban resistif murni. Daya nyata dimanfaatkan untuk mengubah suatu energi listrik menjadi bentuk energi lain.

2) Daya Reaktif $(Q)$

Daya reaktif cukup sulit untuk didefinisikan, secara sederhana daya reaktif adalah daya imajiner (khayal) yang menunjukkan adanya pergeseran arus dan tegangan listrik akibat adanya beban reaktif. Satuan daya ini adalah VAR (Volt Ampere Reactive)

3) Daya Sетu (S)

Daya semu atau disebut juga dengan daya total ( apparent power ). Daya total tersebut ada yang dihamburkan atau diserap kembali pada rangkaian arus bolak balik (AC). Daya semu juga merupakan hasil kali dari Tegangan dan Arus dengan satuan VA (Volt Ampere).

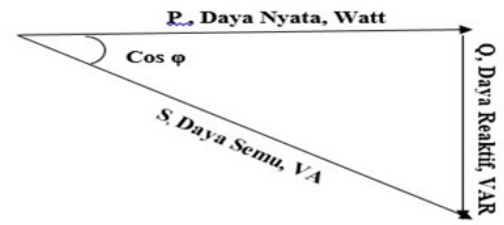

Gambar 1. Segitiga Daya

\section{B. Faktor Daya}

Faktor daya atau faktor kerja adalah perbandingan antara daya aktif (watt) dengan daya semu / daya total (VA) atau cosinus sudut antara daya aktif dan daya semu [1]. Faktor daya sering disebut dengan $\cos p h i(\cos \varphi)$.

Faktor daya yang rendah atau penurunan faktor daya dapat menimbulkan berbagai kerugian, antara lain :

1. Memperbesar kebutuhan KVA

2. Penurunan efisiensi penyaluran daya

3. Memperbesar rugi - rugi panas kawat dan peralatan

4. Mutu listrik menjadi rendah karena adanya drop tegangan.

Dari definisi serta hubungan segitiga daya pada Gambar 1. maka didapatkan persamaan [2] sebagai berikut :

$$
\begin{aligned}
& P=S \cos \varphi \\
& S=\sqrt{P^{2}+Q^{2}} \\
& Q=\sqrt{S^{2}-P^{2}}
\end{aligned}
$$

di mana $\mathrm{P}=$ daya aktif, $\mathrm{S}=$ daya semu, $\mathrm{Q}=$ daya reaktif, dan $\cos \varphi$ adalah sudut faktor daya.

\section{Kompensasi Daya Reaktif}

Kompensasi daya reaktif merupakan suatu cara untuk mengurangi daya reaktif, karena daya reaktif daya tidak berguna sehingga tidak dapat diubah menjadi tenaga akan tetapi diperlukan untuk proses transmisi energi listrik pada beban, jadi yang menyebabkan pemborosan energi listrik adalah banyaknya peralatan yang bersifat induktif, otomatis dengan banyaknya peralatan yang bersifat induktif maka faktor daya yang diperoleh sangat kecil. Salah satu upaya optimalisasi pemanfaatan energi listrik yang dapat dilakukan adalah dengan perbaikan jaringan distribusi berupa kompensasi daya reaktif dengan peningkatan faktor daya dengan pemasangan kapasitor bank (capasitor bank) [6], [7], [8], [3], [9], [10], [11], [12], [13], [14], [15]. Kapasitor yang dipasang paralel pada beban sehingga pengaturan faktor daya dapat dilakukan, sehingga pada kompensasi tersebut mengatur arus pada kapasitor dan akan mendapatan faktor daya yang diinginkan (lebih dari 0,85). Biaya Kelebihan Pemakaian Daya Reaktif dikenakan untuk pemakaian tenaga listrik dengan faktor daya rata-rata setiap bulan kurang dari 0,85 [16], [17]

Kompensasi daya reaktif dapat di lakukan dengan memperbaiki faktor daya, seperti pada Gambar 2. [2], [9]

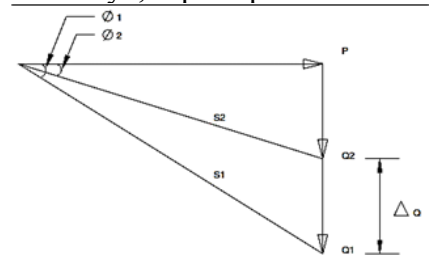

Gambar 2. Segitiga Perbaikan Faktor Daya [2]

Perbaikan faktor daya dilakukan dengan memperbaiki cos $\varphi_{1}$ menjadi $\cos \varphi_{2}$, dengan demikian dapat dihitung besarnya kapasitas kapasitor bank yang akan dipasang [2]:

Saat keadaan awal $\left(\cos \varphi_{1}\right)$, terdapat variable $\mathrm{P}, \mathrm{S}_{1}, \mathrm{Q}_{1}$ :

$$
\begin{aligned}
& S_{1}=\sqrt{P^{2}+Q_{1}{ }^{2}} \\
& Q_{1}=\sqrt{S_{1}{ }^{2}-P^{2}}
\end{aligned}
$$

Perbaikan faktor daya target adalah $\cos \varphi_{2}$, terdapat variable $\mathrm{P}, \mathrm{S}_{2}, \mathrm{Q}_{2}$ :

$$
\begin{aligned}
& S_{2}=\frac{P}{\cos \varphi_{2}} \\
& Q_{2}=\sqrt{S_{2}{ }^{2}-P^{2}}
\end{aligned}
$$

Besarnya kompensasi daya reaktif atau kapasitas kapasitor bank (KVAR) adalah :

$$
\Delta Q=Q_{1}-Q_{2}
$$

\section{METODE PENELITIAN}

\section{A. Lokasi Penelitian}

Lokasi penelitian untuk penulisan ini dilakukan di Instalasi Wing Amerta RSUP Sanglah Denpasar yang beralamat di Jalan Diponegoro No.1 Denpasar, waktu penelitiannya dimulai sejak Oktober 2018 sampai dengan Maret 2019.

\section{B. Sumber data}

Sumber data yang dipakai berupa :

\section{1) Data primer}

Data yang diperoleh dari pengukuran daya listrik bebanbeban yang dioperasikan di Instalasi Wing Amerta RSUP Sanglah Denpasar dan studi literatur yang berkaitan dengan tema pembahasan.

2) Data sekunder 
Majalah Ilmiah Teknologi Elektro, Vol. 18, No. 2, Mei - Agustus 2019

DOI: https://doi.org/10.24843/MITE.2019.v18i02.P14

Data yang diperoleh secara tidak langsung dan bersumber dari RSUP Sanglah Denpasar, single line diagram sistem kelistrikan, rekening pembayaran listrik pada tahun 2016, 2017, 2018, denah, luas bangunan gedung, inventaris AC, peralatan medis, penerangan dan peralatan lainnya tahun 2018 .

\section{Jenis data}

Jenis data pada penelitian ini adalah :

1) Data kuantitatif

Adalah data dalam bentuk angka-angka seperti jumlah peralatan listrik, kapasitas daya, jumlah pemakaian listrik.

\section{2) Data kualitatif}

Adalah data dalam bentuk kata-kata (kalimat) seperti penjelasan gambar, objek penelitian.

\section{Metode Pengumpulan Data}

Bentuk metode penelitian data dilakukan dengan beberapa cara yaitu :

1) Metode observasi

Teknik pengumpulan data dengan mengadakan pengamatan dan pengambilan hasil pengukuran tegangan, arus, $\cos \varphi$, daya aktif, daya reaktif dan daya semu pada objek penelitian. Studi literatur, yaitu teknik pengumpulan data dari buku-buku, jurnal, tesis dan hasil penelitian yang terkait kualitas daya listrik.

2) Dokumentasi

Data yang diperoleh dari arsip atau dokumen milik rumah sakit atau dokumentasi pribadi.

D. Alur Penelitian

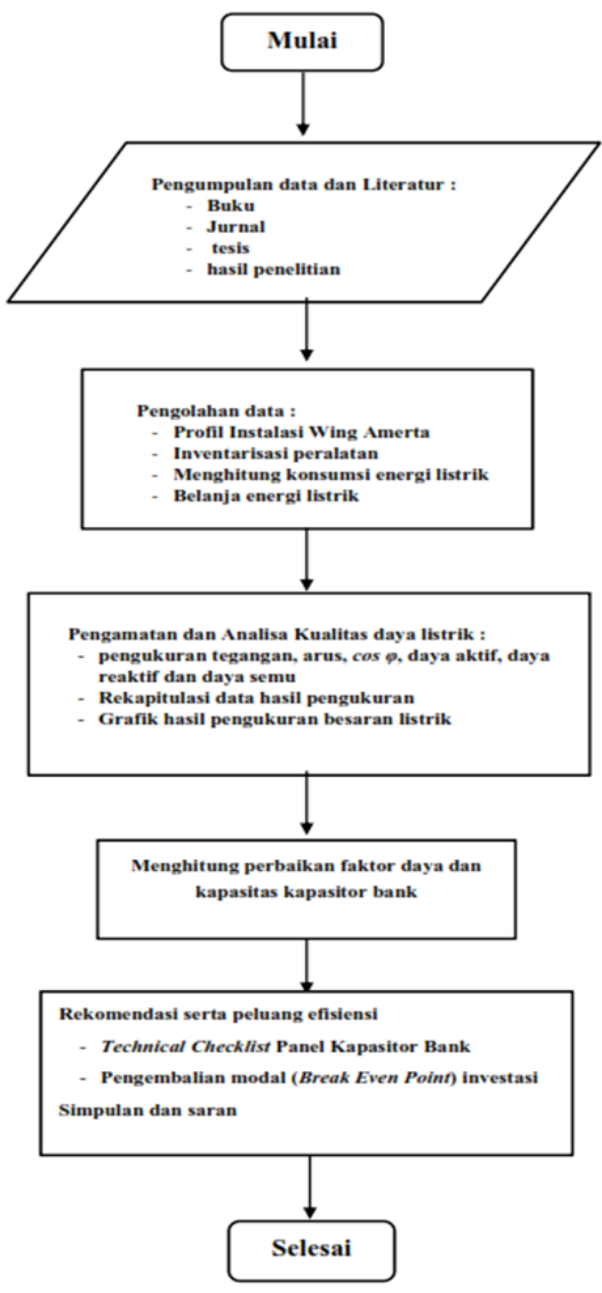

Gambar 3. Alur Penelitian

\section{HASIL DAN PEMBAHASAN}

\section{A. Inventaris Peralatan listrik di Wing Amerta RSUP Sanglah}

TABEL I

INVENTARISASI JUMLAH PERALATAN

\begin{tabular}{|l|c|c|}
\hline Klasifikasi & $\begin{array}{c}\text { Jumlah } \\
\text { Alat }\end{array}$ & Persentase \\
\hline AC & 116 & $14 \%$ \\
\hline $\begin{array}{l}\text { Peralatan } \\
\text { Medis }\end{array}$ & 198 & $23 \%$ \\
\hline Penerangan & 427 & $50 \%$ \\
\hline Lainnya & 110 & $13 \%$ \\
\hline \multicolumn{1}{|r|}{ total } & $\mathbf{8 5 1}$ & $\underline{\mathbf{1 0 0} \%}$ \\
\hline
\end{tabular}

I Putu Meyyasa: Analisa Kualitas Daya Listrik ... 


\section{Inventarisasi Jumlah Peralatan}

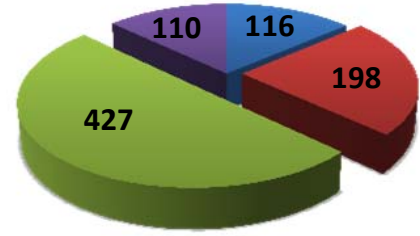

$\square \mathrm{AC}$

- Peralatan Medis

Penerangan

- Lainnya

Gambar 4. Inventarisasi jumlah Peralatan

B. Konsumsi Energi Listrik di Instalasi Wing Amerta

Besarnya konsumsi energi listrik dari keseluruhan pengelompokan peralatan yang ada yaitu berupa kelompok peralatan sistem pencahayaan, penataan udara, peralatan medis, dan peralatan lainnya. Data ini berisi tentang nama gedung, lantai, daya listrik alat, daya kuda (PK / HP [18], jumlah jam operasional/jam kerja, jenis alat, merek, jumlah (kuantitas), serta jumlah konsumsi energi yang diserap perjam dalam sehari pemakaian (KWh/hari). Data data tersebut didapat dari data inventaris milik Instalasi Wing Amerta, asumsi lama pemakaian alat per hari, data dari acuan literatur serta data berdasarkan perhitungan matematis. Hasil perhitungan ini diharapkan dapat menghasilkan nilai konsumsi energi listrik yang mendekati nilai sebenarnya.

TABEL II

REKAPITULASI KONSUMSI ENERGI LISTRIK KESELURUHAN

\begin{tabular}{|c|c|c|c|c|c|}
\hline Klasifikasi & $\begin{array}{c}\Sigma \text { daya } \\
(\mathrm{KW})\end{array}$ & $\begin{array}{c}\Sigma \text { Energi } \\
\text { (KWh/ } \\
\text { hari) }\end{array}$ & $\begin{array}{l}\Sigma \text { Energi } \\
\text { (KWh / } \\
\text { bulan) }\end{array}$ & $\begin{array}{c}\Sigma \text { Energi } \\
\text { (KWh / } \\
\text { tahun) }\end{array}$ & $\begin{array}{c}\text { Persenta } \\
\text { se }(\%)\end{array}$ \\
\hline $\mathrm{AC}$ & 181,278 & $2.333,115$ & $34.515,49$ & $414.185,88$ & $76,34 \%$ \\
\hline $\begin{array}{l}\text { Peralatan } \\
\text { Medis }\end{array}$ & 36,85 & 98,61 & $2.242,13$ & $26.905,56$ & $3,23 \%$ \\
\hline Penerangan & 9,33 & 98,155 & $2.052,70$ & $24.632,40$ & $3,21 \%$ \\
\hline $\begin{array}{l}\text { Peralatan } \\
\text { lain }\end{array}$ & 26,045 & 526,28 & $11.578,05$ & $138.936,60$ & $17,22 \%$ \\
\hline total daya & 253,503 & $3.056,16$ & $\mathbf{5 0 . 3 8 8 , 3 7}$ & $604.660,44$ & $100 \%$ \\
\hline
\end{tabular}

Tabel II dapat diketahui kebutuhan pemakaian daya listrik terbesar berasal dari kelompok peralatan penataan udara sebesar 181,278 KW diikuti oleh kelompok peralatan medis sebesar 36,85 KW, selanjutnya dari kelompok peralatan lain sebesar 26,045 KW, dan terakhir dari kelompok penerangan sebesar 9,33 KW. Untuk konsumsi energi listrik (KWh/hari) terbesar adalah berasal dari kelompok peralatan penataan udara (AC) yaitu sebesar 76,34\% diikuti oleh kelompok peralatan lain sebesar $17,22 \%$, kelompok peralatan medis sebesar 3,23\%, konsumsi terkecil adalah pada kelompok penerangan sebesar $3,21 \%$.

Untuk mengetahui lebih jelas komposisi Daya dan konsumsi energi listrik di Instalasi Wing Amerta RSUP Sanglah Denpasar secara keseluruhan dapat dilihat pada Gambar 5. dan Gambar 6.

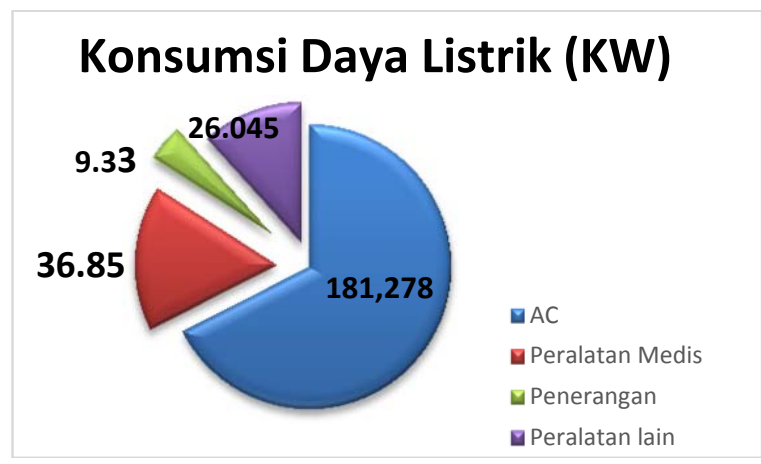

Gambar 5. Konsumsi Daya Listrik keseluruhan

\section{Persentasi Konsumsi Energi Listrik (KWh/hari)}

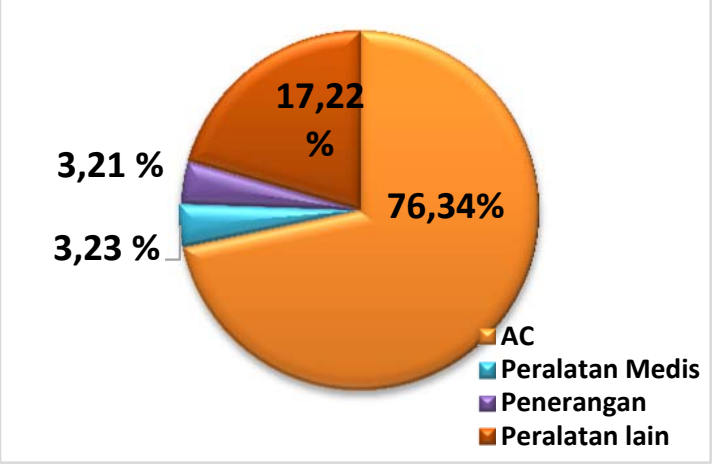

Gambar 6. Persentase Konsumsi Energi Listrik

\section{Belanja Energi Listrik}

Instalasi Wing Amerta mempunyai sebuah power house yang dilengkapi dengan meteran dari PLN dengan Id Pelanggan : 551002509709 , Tarif / Daya : S3 / 555000 VA. Berikut ini adalah belanja energi listrik dari tahun 2016, 2017, 2018 dijelaskan pada Tabel III.

TABEL III

BELANJA ENERGI LISTRIK WING AMERTA

\begin{tabular}{||c|c|c|c||}
\hline \multirow{2}{*}{ Bulan } & \multicolumn{3}{|c||}{ Tahun } \\
\cline { 2 - 4 } & 2016 & 2017 & 2018 \\
\hline
\end{tabular}


Majalah Ilmiah Teknologi Elektro, Vol. 18, No. 2, Mei - Agustus 2019

DOI: https://doi.org/10.24843/MITE.2019.v18i02.P14

\begin{tabular}{||l|l|l|l||} 
Januari & 73.418 .220 & 30.769 .140 & 37.653 .880 \\
\hline Februari & 61.404 .540 & 30.984 .640 & 37.278 .215 \\
\hline Maret & 48.318 .600 & 31.819 .045 & 36.695 .780 \\
\hline April & 65.770 .860 & 35.127 .995 & 41.243 .320 \\
\hline Mei & 56.311 .620 & 33.612 .565 & 37.034 .455 \\
\hline Juni & 65.265 .180 & 31.494 .675 & 34.211 .770 \\
\hline Juli & 52.314 .900 & 25.758 .810 & 37.004 .232 \\
\hline Agustus & 37.390 .235 & 26.682 .260 & 39.033 .080 \\
\hline September & 34.224 .740 & 28.803 .050 & 34.252 .345 \\
\hline Oktober & 30.743 .470 & 26.929 .340 & 32.957 .665 \\
\hline Nopember & 32.884 .020 & 29.427 .540 & 35.491 .035 \\
\hline Desember & 31.863 .840 & 33.672 .620 & 32.297 .935 \\
\hline & & & \\
\hline Total per tahun & 589.910 .225 & 365.081 .680 & 435.153 .712 \\
\hline \multirow{2}{*}{ Rata-rata selama } & & & 36.262 .809 \\
\hline
\end{tabular}

\section{Biaya Konsumsi Listrik Wing Amerta}

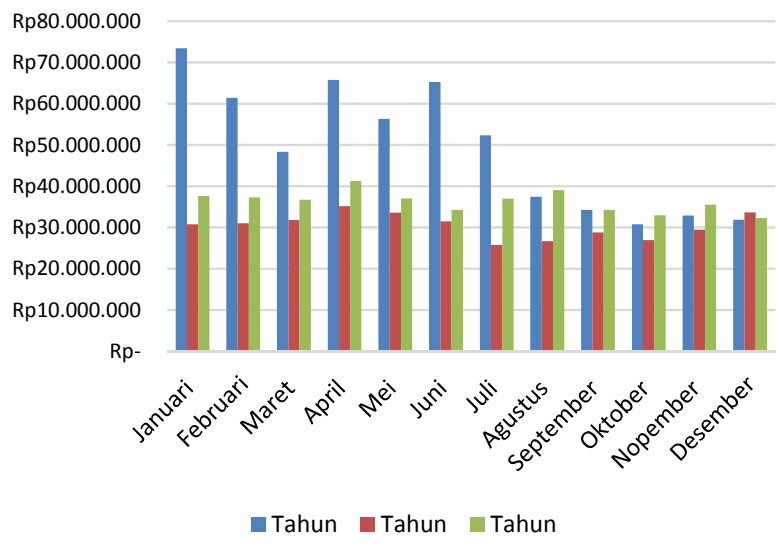

Gambar 7. Belanja Energi Listrik Wing Amerta

Besarnya biaya belanja energi pada Tabel III dan Gambar 7, biaya konsumsi terbesar pada tahun 2016 sebesar Rp. 589.910.225, disusul tahun 2018 Rp. 435.153 .712 dan tahun 2017 Rp. 365.081.680. Hal ini dipengaruhi oleh tingkat kunjungan rawat jalan dan hunian rawat inap. Dari besarnya biaya belanja energi secara keseluruhan, terdapat biaya konsumsi kelebihan KVARh yang di tampilkan pada Tabel IV dan Gambar 8.

TABEL IV

BIAYA KONSUMSI KELEBIHAN KVARH

\begin{tabular}{||c|c|c|c||}
\hline \multirow{2}{*}{ Bulan } & \multicolumn{3}{|c|}{ Tahun } \\
\cline { 2 - 4 } & 2016 & 2017 & 2018 \\
\hline Januari & 17.878 .400 & 2.242 .200 & 4.199 .500 \\
\hline
\end{tabular}

I Putu Meyyasa: Analisa Kualitas Daya Listrik ...

\begin{tabular}{||l|r|r|r|} 
& \multicolumn{3}{c}{253} \\
\hline Februari & 14.962 .800 & 3.133 .900 & 4.649 .975 \\
\hline Maret & 9.645 .900 & 3.242 .125 & 4.702 .700 \\
\hline April & 14.711 .200 & 3.184 .775 & 6.130 .900 \\
\hline Mei & 10.700 .400 & 3.586 .225 & 1.116 .475 \\
\hline Juni & 13.053 .600 & 1.956 .375 & 1.862 .950 \\
\hline Juli & 8.658 .000 & 1.727 .900 & 7.733 .925 \\
\hline Agustus & 4.694 .375 & 895.400 & 9.053 .900 \\
\hline September & 2.948 .900 & 1.866 .650 & 6.916 .225 \\
\hline Oktober & 2.195 .950 & 1.239 .500 & 4.563 .025 \\
\hline Nopember & 4.890 .475 & 1.125 .500 & 3.725 .450 \\
\hline Desember & 6.250 .500 & 3.581 .600 & 6.550 .750 \\
\hline Total per tahun & 110.590 .500 & 27.782 .150 & 61.205 .775 \\
\hline Total 3 tahun & \multicolumn{3}{|c|}{199.578 .425} \\
\hline Rata-rata setahun & & $66,526,141.67$ & \\
\hline Rata-rata sebulan & & $5,543,845.14$ & \\
\hline \hline
\end{tabular}

Biaya Kelebihan Konsumsi Daya Reaktif (KVARH)

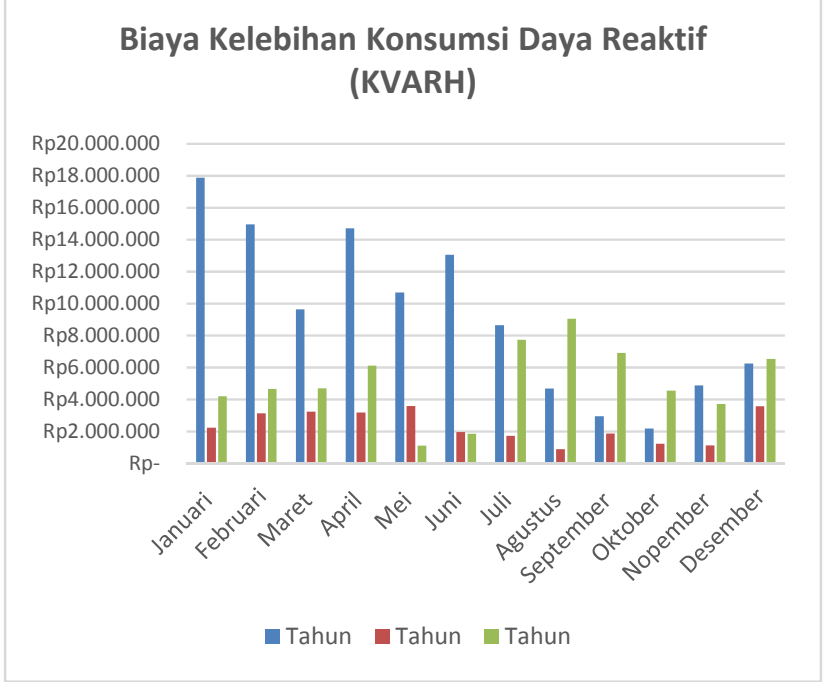

Gambar 8. Biaya Konsumsi Kelebihan kVarh

Pemakaian daya reaktif dapat dilihat pada Tabel IV, sehingga ada denda yang harus dibayar oleh pihak RSUP Sanglah. Selain adanya denda yang harus dibayar munculnya KVARH dapat merugikan kualitas daya listrik yang disebabkan oleh beberapa faktor daya yang kurang dari 0,85 [16]. Daya reaktif dibutuhkan oleh beban agar dapat beroperasi. Beban jenis ini dikenal juga dengan beban induktif, seperti elektromotor pada peralatan medis dan lampu TL. Kompensasi daya reaktif merupakan suatu cara untuk mengurangi daya reaktif. Salah satu cara mengatasi hal di atas adalah dengan pemasangan kapasitor bank. Untuk memperbaiki faktor daya akan dilakukan pengukuran parameter tertentu yang nantinya akan digunakan sebagai penghitungan besarnya kompensasi daya reaktif.

p-ISSN:1693 - 2951; e-ISSN: 2503-2372

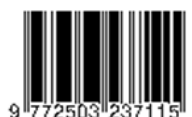


D. Pengamatan dan Analisa Kualitas daya listrik Eksisting

Untuk mengetahui pemakaian daya yang sesungguhnya maka diadakan pengukuran data yang dilakukan di lokasi gardu induk Wing Amerta rentang waktu dari jam 08.00 19.00 WITA dengan tujuan mencari data besaran listrik pada saat beban puncak. Pengukuran dilakukan pada keluaran trafo PLN dengan menggunakan alat ukur Clam On Power HiTester 3286-20 merek HIOKI. Alat ukur ini mampu mengukur parameter- parameter yang diperlukan, antara lain: arus, tegangan, faktor daya, pada pengukuran satu fasa dan untuk sistem tiga fasa mampu mengukur daya aktif, daya reaktif dan daya semu. Kegiatan pengukuran dapat dilihat pada Gambar 9.

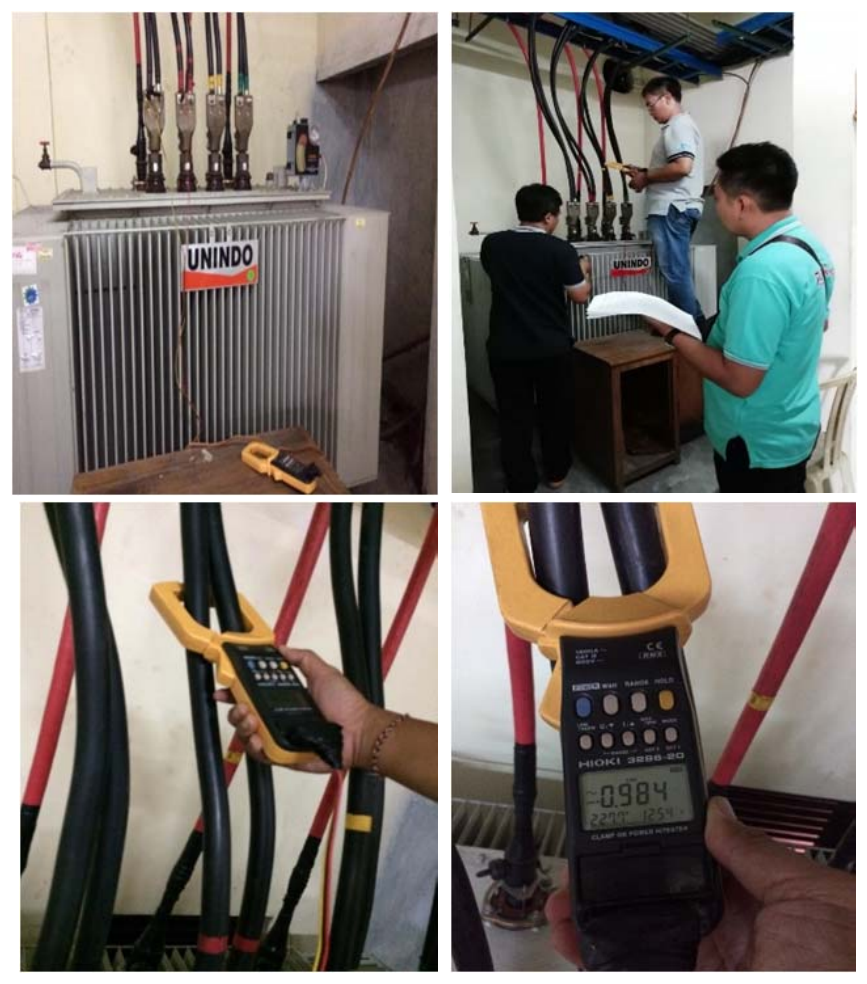

Gambar 9. Kegiatan pengukuran besaran listrik

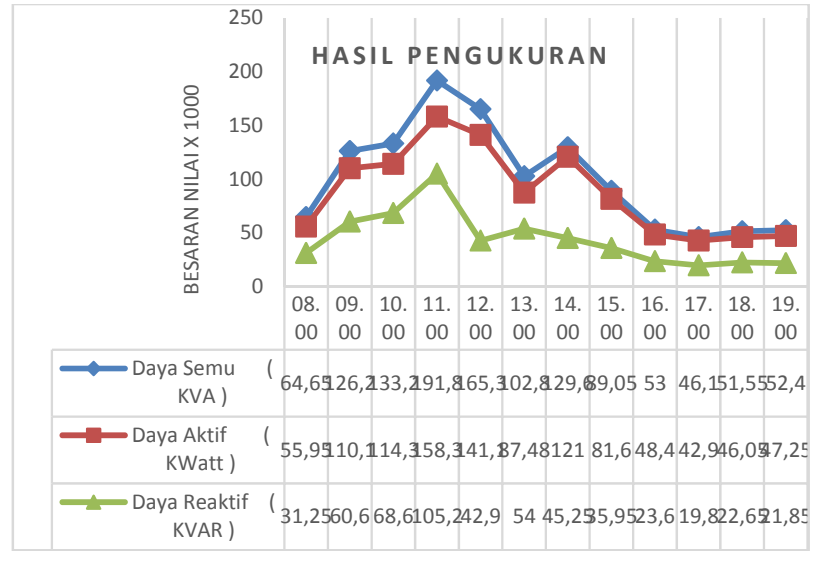

Gambar 10. Grafik hasil pengukuran besaran listrik

TABEL V

DATA HASIL PENGUKURAN

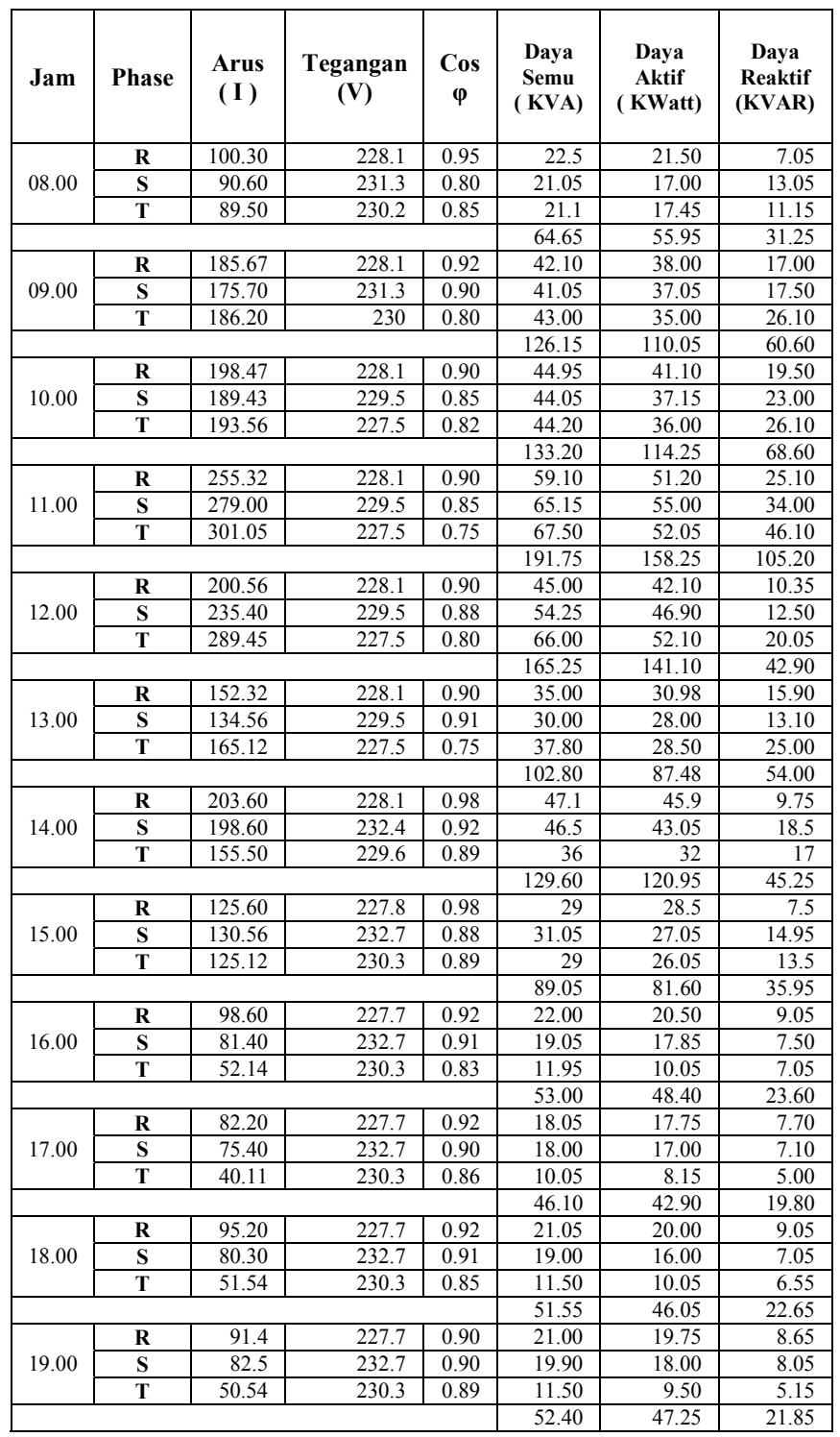


Dari Gambar 10 dapat diketahui beban puncak berada pukul 11.00 WITA dengan data daya semu 191,75 KVA, daya aktif 158,25 KW dan daya reaktif sebesar 105,2 KVAR dengan faktor daya 0,75 . Data ini nantinya dipakai acuan menghitung perbaikan faktor daya.

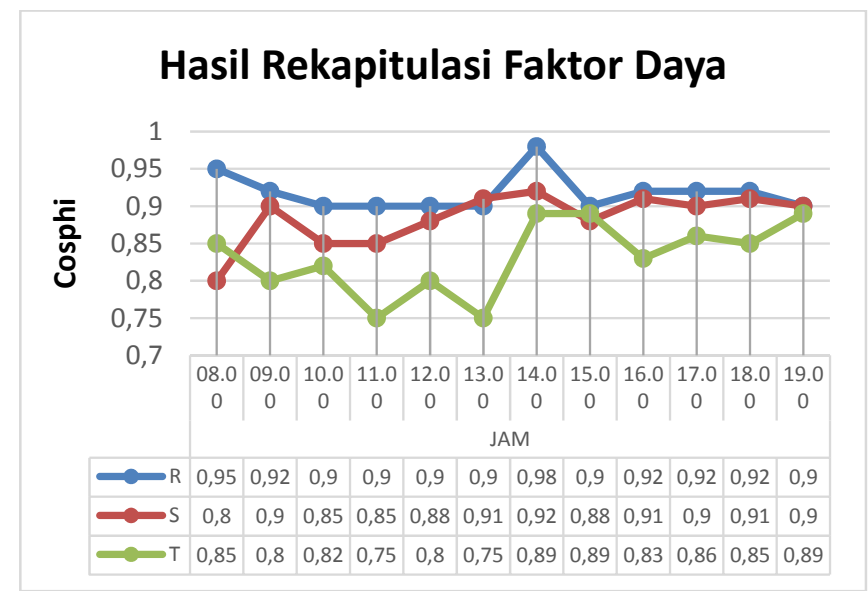

Gambar 11. Grafik hasil pengukuran Faktor Daya

Dari Gambar 11 didapat :

1. Faktor daya dibawah 0,85 : Phase $\mathrm{R}$ : tidak ada, Phase $\mathrm{S}$ : 1 kali (jam 08.00), Phase T : 6 kali (jam 9, 10, 11, 12, 13, 16)

2. Faktor daya mempengaruhi daya aktif (P) dan daya reaktif $(\mathrm{Q})$;

a. Semakin kecil faktor daya, maka daya aktif menjadi semakin kecil dan daya reaktif menjadi semakin besar.

b. Semakin besar faktor daya, maka daya aktif menjadi semakin besar dan daya reaktif menjadi semakin kecil. Faktor daya berbanding lurus dengan daya aktif dan berbanding terbalik dengan daya reaktif.

3. Pada phase T, lebih banyak beban - beban induktif, seperti elektromotor, dan lampu TL. Beban induktif diciptakan oleh lilitan kawat (kumparan) yang terdapat di berbagai alat-alat listrik seperti motor, trafo, dan relay. Kumparan dibutuhkan oleh alat-alat listrik tersebut untuk menciptakan medan magnet sebagai komponen kerjanya. Pembangkitan medan magnet pada kumparan inilah yang menjadi beban induktif pada rangkaian arus listrik AC.

\section{E. Menghitung perbaikan faktor daya dan kapasitas} kapasitor bank

Dengan mengetahui besaran listrik sesuai dengan pengukuran diatas, maka dapat dilakukan perbaikan faktor daya sesuai dengan yang diinginkan:

1) Perbaikan faktor daya menjadi 0,86

yaitu perbaikan minimum supaya konsumen tidak menanggung biaya kelebihan KVARH dari PLN, dengan menghitung kapasitas panel kapasitor bank sebagai berikut :

Diketahui :

a. Kapasitas daya maksimum untuk Wing Amerta (S) : $555 \mathrm{KVA}$

I Putu Meyyasa: Analisa Kualitas Daya Listrik ... b. Faktor daya pada saat beban puncak $(\cos p h i): 0,75$

Maka besarnya Daya Aktif (P) adalah :

$$
\begin{aligned}
P & =S \cos \varphi \\
& =555 \mathrm{KVA} \times 0,75 \\
& =416,250 \mathrm{KW}
\end{aligned}
$$

Saat keadaan awal $\left(\cos \varphi_{1}\right)=0,75$

Daya Reaktif $\left(Q_{1}\right)$ dapat dihitung :

$$
\begin{aligned}
Q_{1} & =\sqrt{S_{1}{ }^{2}-P^{2}} \\
& =\sqrt{555^{2}-416,250^{2}} \\
& =\sqrt{308.025-173.265} \\
& =\sqrt{134.761} \\
& =\mathbf{3 6 7 , 0 9 8 ~ K V A R}
\end{aligned}
$$

Perbaikan faktor daya target adalah $\cos \varphi_{2}=0,86$ didapat :

$$
\begin{aligned}
S_{2} & =\frac{P}{\cos \varphi_{2}} \\
& =416,250 / 0,86 \\
& =\mathbf{4 8 4 , 0 1 2 ~ K V A} \\
Q_{2} & =\sqrt{S_{2}{ }^{2}-P^{2}} \\
Q_{2} & =\sqrt{484,012^{2}-P 416,250^{2}} \\
& =\sqrt{234.267-173.264} \\
& =\sqrt{61.003} \\
& =\mathbf{2 4 6 , 9 8 8}
\end{aligned}
$$

Besarnya kapasitas kapasitor bank (KVAR) adalah :

$$
\begin{aligned}
\Delta Q & =Q_{1}-Q_{2} \\
& =367,098-246,988 \\
& =\mathbf{1 6 2 , 4 6 5} \text { KVAR }
\end{aligned}
$$

\section{2) Perbaikan faktor daya menjadi 0,98}

yaitu perbaikan untuk mendapatkan daya aktif maksimal yang disediakan PLN, dapat dihitung sebagai berikut,

Perbaikan faktor daya target adalah $\cos \varphi_{2}=0,98$ didapat:

$$
\begin{aligned}
& S_{2}=\frac{P}{\cos \varphi_{2}} \\
& =416,250 / 0,98 \\
& =424,745 \mathrm{KVA} \\
& Q_{2}=\sqrt{S_{2}{ }^{2}-P^{2}} \\
& Q_{2}=\sqrt{424,745^{2}-P 416,250^{2}} \\
& =\sqrt{180.408-173.264} \\
& =\sqrt{7.144} \\
& =\mathbf{8 4 , 5 2 3}
\end{aligned}
$$

Besarnya kapasitas kapasitor bank (KVAR) adalah :

$$
\begin{aligned}
\Delta Q & =Q_{1}-Q_{2} \\
& =367,098-84,523 \\
& =\mathbf{2 8 2 , 5 7 5} \text { KVAR }
\end{aligned}
$$

Hasil perhitungan dapat dilihat pada Tabel VI, Gambar 12 dan Gambar 13.
p-ISSN:1693 - 2951; e-ISSN: 2503-2372

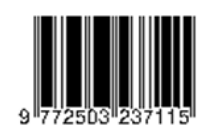


TABEL VI

PERHITUNGAN KAPASITAS KAPASITOR BANK

\begin{tabular}{|c|c|c|c|c|c|c|}
\hline Diketahui : & $\begin{array}{c}\mathrm{S}_{1} \\
(\mathrm{KVA})\end{array}$ & $\begin{array}{c}\mathrm{P} \\
(\mathrm{KW})\end{array}$ & $\begin{array}{c}\mathrm{Q}_{1} \\
(\mathrm{KVAR})\end{array}$ & $\begin{array}{c}\mathrm{S}_{2} \\
(\mathrm{KVA})\end{array}$ & $\begin{array}{c}\mathrm{Q}_{2} \\
\text { (KVAR) }\end{array}$ & $\begin{array}{c}\Delta \mathrm{Q} \\
(\mathrm{KVAR})\end{array}$ \\
\hline $\mathrm{PF}_{1}=0,75$ & 555 & 416,250 & 367,098 & & & \\
\hline & & & & & & \\
& & & & 484,012 & 246,988 & $\mathbf{1 6 2 , 4 6 5}$ \\
\hline $\mathrm{PF}_{2}=0,86$ & & & & & & \multirow{2}{282,575}{} \\
\hline
\end{tabular}

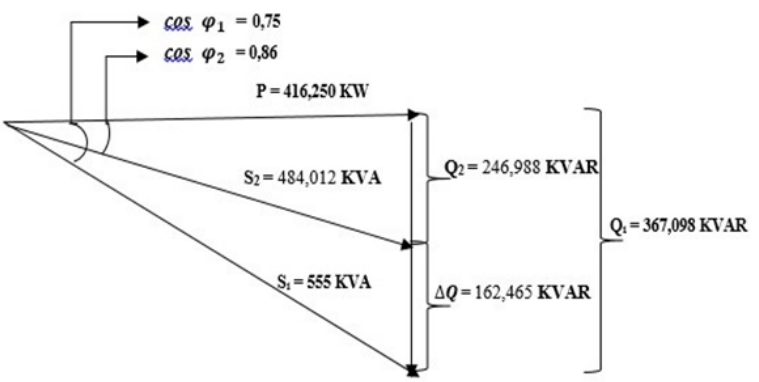

Gambar 12. Perhitungan kapasitas kapasitor bank $\cos \varphi_{2}=0,86$

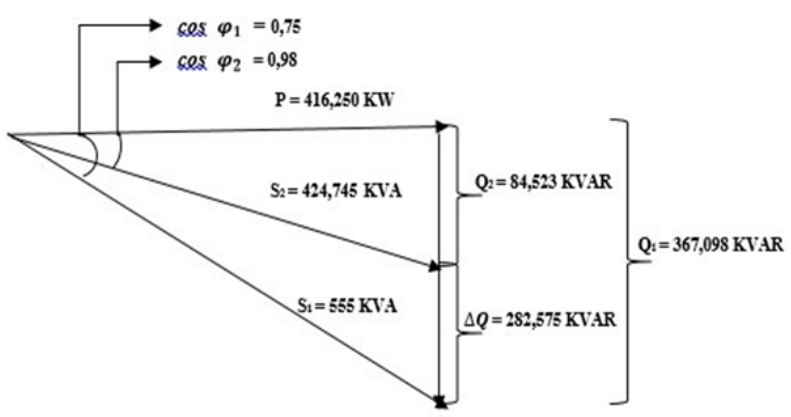

Gambar 13. Perhitungan kapasitas kapasitor bank $\cos \varphi_{2}=0,98$

\section{F. Rekomendasi serta peluang efisiensi}

Dari hasil perhitungan perbaikan faktor daya serta besarnya kapasitas kapasitor bank, dibutuhkan survei harga serta spesifikasi atau technical ceklist panel kapasitor bank yang akan dipasang. Sesuai hasil survei harga, pengalaman, konsultasi beberapa tenaga ahli, serta kapasitas yang ada di pasaran didapatkan spesifikasi kapasitas kapasitor bank sesuai dengan tabel VII.

TABEL VII

SPESIFIKASI SERTA INVESTASI KAPASITOR BANK

\begin{tabular}{|c|c|c|c|c|c|}
\hline Iter & & $\begin{array}{c}\text { Efisiensi } \\
\text { pembayaran } \\
\text { KVARH } \\
\text { rata-rata/ } \\
\text { bulan }(\mathrm{Rp}) \\
\end{array}$ & $\begin{array}{c}\text { Efisiensi } \\
\text { pembayaran } \\
\text { KVARH } \\
\text { rata-rata/ } \\
\text { tahun (Rp) }\end{array}$ & $\begin{array}{c}\text { Break } \\
\text { Even } \\
\text { Point } \\
\text { (Tahun) }\end{array}$ & Keterangan \\
\hline $\begin{array}{l}\text { Keuntungan } \\
\text { (Efisiensi } \\
\text { pembayaran } \\
\text { KVARH) }\end{array}$ & & 5.543 .845 & 66.526 .141 & & \\
\hline Investasi & 200 & & & 1,5 & Kapasitas \\
\hline
\end{tabular}

\begin{tabular}{|c|c|c|c|l|}
\hline $\begin{array}{c}\text { (pembelian } \\
\text { kapasitor } \\
\text { bank) (Rp) }\end{array}$ & KVAR & 100.000 .000 & $\begin{array}{c}(18 \\
\text { bulan) }\end{array}$ & $\begin{array}{l}\text { minimum tidak } \\
\text { membayar } \\
\text { kelebihan kvarh }\end{array}$ \\
\cline { 2 - 5 } & & & & $\begin{array}{l}\text { Dapat } \\
\text { memaksimalkan } \\
\text { daya aktif yang } \\
\text { disediakan PLN } \\
\text { dan } \\
\text { penambahan } \\
\text { beban daya di } \\
\text { than } \\
\text { berikutnya }\end{array}$ \\
\hline
\end{tabular}

Setelah mempertimbangkan data dari tabel VII diatas, direkomendasikan pemasangan kapasitor bank dengan kapasitas sebesar 360 KVAR dengan pertimbangan dapat memaksimalkan daya aktif yang disediakan PLN serta kebutuhan penambahan beban daya ditahun berikutnya. Harga panel kapasitor bank 360 KVAR sebesar Rp. 120.000.000,(seratus dua puluh juta rupiah) dengan rincian pada tabel VIII.

TABEL VIII

TECHNICAL CHECKLIST PANEL KAPASITOR BANK 360 KVAR 12 STEP

\begin{tabular}{|c|c|c|c|c|c|}
\hline No & Nama Barang & Jumlah & Satuan & Merek & Type \\
\hline 1 & $\begin{array}{l}\text { Box Panel H1600 } \\
\text { W1400 D600mm } \\
\text { Powder Coating } \\
\text { Plat } 2,0 \mathrm{~mm}\end{array}$ & 1 & Unit & Local & $\begin{array}{l}\text { Indoor / Free } \\
\text { Standing }\end{array}$ \\
\hline 2 & $\begin{array}{l}\text { Load Break Switch } \\
\text { 3P 630A }\end{array}$ & 1 & Pcs & Socomec & Sirco \\
\hline 3 & $\begin{array}{l}\text { MCCB 3P 50A } \\
7,5 \mathrm{kA}\end{array}$ & 16 & Pcs & Schneider & EZC100B3050 \\
\hline 4 & $\begin{array}{l}\text { MCCB 3P 40A } \\
7,5 \mathrm{kA}\end{array}$ & 4 & Pcs & Schneider & EZC100B3040 \\
\hline 5 & $\begin{array}{l}\text { Selector Switch A - } \\
\mathrm{O}-\mathrm{M}\end{array}$ & 1 & Pcs & Fort & 3 Possion \\
\hline 6 & Relay + Socket & 3 & Pcs & Omron & MY4 220Volt \\
\hline 7 & $\begin{array}{l}\text { MCB 1P 10A } \\
4,5 \mathrm{kA}\end{array}$ & 3 & Pes & Schneider & Domae \\
\hline 8 & $\begin{array}{l}\text { Power Factor } \\
\text { Regulator } 12 \text { Step }\end{array}$ & 1 & Pcs & $\begin{array}{c}\text { Epcos } \\
\text { MH }\end{array}$ & $\mathrm{MSC} 12 \mathrm{~N}$ \\
\hline 9 & $\begin{array}{l}\text { Kapasitor Bank } \\
\text { 20kVar 415Volt }\end{array}$ & 16 & Pcs & GAE & MKPg \\
\hline 10 & $\begin{array}{l}\text { Kapasitor Bank } \\
10 \mathrm{kVar} 415 \text { Volt }\end{array}$ & 4 & Pcs & GAE & MKP \\
\hline 11 & $\begin{array}{l}\text { Magnetic } \\
\text { Contactor } \\
\text { Capacitor 20kVar }\end{array}$ & 16 & Pcs & Schneider & LC1DLK12M7 \\
\hline 12 & $\begin{array}{l}\text { Magnetic } \\
\text { Contactor } \\
\text { Capacitor 10kVar }\end{array}$ & 4 & Pcs & Schneider & LC1DFK12M7 \\
\hline 13 & $\begin{array}{l}\text { Exhaust Fan } 10 \\
\text { Inch }\end{array}$ & 1 & Pcs & Panasonic & FV25TGU \\
\hline 14 & Busbar CU & 1 & Lot & Imfort & $10 \mathrm{~mm} \times 40 \mathrm{~mm}$ \\
\hline 15 & $\begin{array}{l}\text { Busbar Holder } \\
5 \mathrm{~mm}\end{array}$ & 1 & Lot & Ewig & $5 \mathrm{~mm}$ \\
\hline 16 & $\begin{array}{l}\text { Kabel NYAF } \\
10 \mathrm{~mm}\end{array}$ & 100 & Meter & 4 besar & NYAF \\
\hline 17 & $\begin{array}{l}\text { Kabel Control } \\
\text { NYAF } 0,75 \mathrm{~mm}\end{array}$ & 300 & Meter & 4 besar & NYAF \\
\hline 18 & Pilot Lamp & 3 & Pcs & Fort & LED \\
\hline 19 & $\begin{array}{l}\text { Push Button On } \\
\text { Lamp Green }\end{array}$ & 12 & Pcs & Hanyoung & CR254-2 \\
\hline 20 & $\begin{array}{l}\text { Push Button Off } \\
\text { Red }\end{array}$ & 12 & Pcs & Hanyoung & CR251-1 \\
\hline 21 & $\begin{array}{l}\text { Accessories,Mur } \\
\text { Baut,Material } \\
\text { Bantu,Scoon,Vynil }\end{array}$ & 1 & Lot & SNI & - \\
\hline
\end{tabular}

Adapun 12 step yang dimaksud adalah 8 step 40 KVAR (320 KVAR) dan 4 step 10 KVAR (40 KVAR), dimana stepstep ini berfungsi untuk perpindahan otomatis apabila ada fluktuasi perubahan besaran KVAR.

Dari data hasil analisis diatas didapatkan bahwa selisih kemahalan investasi yang telah dikeluarkan untuk membeli 
Majalah Ilmiah Teknologi Elektro, Vol. 18, No. 2, Mei - Agustus 2019

DOI: https://doi.org/10.24843/MITE.2019.v18i02.P14

kapasitor bank akan balik modal (Break Even Point [19], [20]) setelah 1,8 tahun atau 22 bulan. Setelah tahun ke dua dan seterusnya, merupakan keuntungan atau efisiensi pengeluaran Rumah Sakit sebesar Rp. 5.543.845,- setiap bulannya atau Rp. 66.526 .141 ,- setiap tahunnya.

Selain keuntungan diatas, dengan di pasangnya kapasitor bank ini diharapkan : Memaksimalkan pemakaian daya (KVA), menghindari kelebihan beban trafo (overload) dan menghindari kenaikan arus / suhu pada kabel.

\section{KESIMPULAN}

Dari hasil penelitian ini dapat diambil kesimpulan yaitu:

1. Perbaikan faktor daya dapat dilakukan dengan pemasangan kapasitor bank dengan kapasitas 360 KVAR yang memerlukan nilai investasi sebesar Rp. 120.000.000,dengan perkiraan balik modal (Break Even Point) setelah 1,8 tahun atau 22 bulan dan keuntungan atau efisiensi pengeluaran Rumah Sakit sebesar Rp. 5.543.845,-- setiap bulannya atau Rp. 66.526.141,-- setiap tahunnya.

2. Adakan pendekatan kepada pihak manajemen agar segera merealisasikan pengadaan kapasitor bank guna mendapatkan efisiensi terhadap pengeluaran anggaran rutin serta perbaikan kualitas daya listrik di Instalasi Wing Amerta.

\section{REFERENSI}

[1] I. W. Rinas, Kualitas Daya Listrik \& Beberapa Solusinya, Denpasar: Udayana University Press, 2017.

[2] C. Sankaran, Power Quality, Washington DC: CRC Press, 2002.

[3] E. W. Rinaldo Jaya Sitorus, "Studi Kualitas Listrik Dan Perbaikan Faktor Daya Pada Beban Listrik Rumah Tangga Menggunakan Kapasitor," DTE FT USU, Medan, 2013.

[4] F. I. P. Maharani Putri, "Analisis Kualitas Daya Akibat Beban Reaktansi Induktif (XL) di Industri," Journal of Electrical Technology, Vol. \%1 av \%2Vol. 3, No. 2, pp. 81-85, 2018.

[5] A. I. A. Ardhin Najadiya Setya, "Efisiensi Energi Listrik Dalam Upaya Meningkatkan Power Quality dan Penghematan Energi Listrik di Gedung Universitas Ciputra (UC) Apartment Surabaya," Jurusan Teknik Elektro, vol. Volume 06 Nomor 03 ,pp. 193 - 202, 2017.

[6] W. H. W. Dinda Ayu Kusumadewi, " Rancang Bangun Panel Capacitor Bank Untuk Perbaikan Faktor Daya Pada Pabrik Triplex Plywood Industry Desa Wonosobo Kec. Srono Kab. Banyuwangi," UNEJ, Banyuwangi, 2014.

[7] U. A. LUY USMAN, "Analisis Kebutuhan Kapasitor Pada Panel Capasitor Bank Untuk Beban 500 KWatt," Jurnal elektronika dan komputer, vol. Vol. 8, nr Elkom, p. 1, 2015.

[8] Z. A. S. Ahmad Bukhari, "Perbaikan Power Faktor Pada Konsumen Rumah Tangga Menggunakan Kapasitor Bank," Jurnal ilmiah mahasiswa, pp. 69-75, 2012.

[9] M. H. d. J. Setiawan, ”Pemasangan Kapasitor Bank Untuk Perbaikan Faktor Daya Pada Panel Utama Listrik Gedung Fakultas Teknik Universitas IBN Khaldun Bogor," Universitas Ibn Khaldun, Bogor, 2016.

[10] W. Handajadi, "Peningkatan Kualitas Daya Listrik dalam Pemakaian Luminer Menggunakan Lampu Hemat Energi (LHE)," Jurnal Teknologi, vol. Volume 7 Nomor 2, pp. 134-140, 2014.

[11] A. Yani, "Pemasangan Kapasitor Bank untuk," Journal of Electrical Technology, vol. Vol.2, p. 3, 2017.

[12] M. F. Hakim, "ANALISIS KEBUTUHAN CAPACITOR BANK BESERTA IMPLEMENTASINYA UNTUK MEMPERBAIKI

I Putu Meyyasa: Analisa Kualitas Daya Listrik ...
257

FAKTOR DAYA LISTRIK DI POLITEKNIK KOTA MALANG," Jurnal ELTEK, vol. Vol 12 Nomor 01, pp. 105-118, 2014.

[13] M. H. Rizal, "Kualitas Daya Listrik Industri," Research Gate, 24 November 2015.

[14] D. R. Nur Yulianti Hidayah, "ANALISIS PERBAIKAN POWER QUALITY UNTUK PENCAPAIAN EFISIENSI ENERGI DI RS. X," Jurnal Sistem Industri, vol. Volume 7 nomor 1, pp. 46-57, 2013.

[15] N. S. Syamsudin Noor, "Efisiensi Pemakaian Daya Listrik Menggunakan Kapasitor Bank," Jurnal POROS TEKNIK, vol. volume 6, pp. $55-102,2014$.

[16] Menteri Energi Dan Sumber Daya Mineral , "Peraturan Menteri Energi Dan Sumber Daya Mineral NO 07 tahun 2010," i Tarif Tenaga Listrik Yang Disediakan Oleh Perusahaan Perseroan PT. PLN, jakarta, 2010.

[17] Menteri Energi Dan Sumber Daya Mineral, "Peraturan Menteri Energi Dan Sumber Daya Mineral No.28 Tahun 2016," i Tarif Tenaga Listrik yang disediakan oleh PT. PLN, Jakarta, 2016.

[18] S. C. ISKANDAR, Mesin Pendingin, Yogyakarta: CV Budi Utama, 2017.

[19] M. Fuad...[et.al], Pengantar Bisnis, Bogor: Gramedia Pustaka Utama, 2000.

[20] C. Y. Rachmat, "Studi Manajemen Energi Di Rumah Sakit Prima Medika Denpasar," Majalah Ilmiah Teknologi Elektro, Vol. \%1 av \%2 Vol. 18, No.1, p. 04, 2019.
p-ISSN:1693 - 2951; e-ISSN: 2503-2372

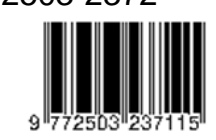

